Check for updates

The BMJ

Cite this as: $B M J$ 2021;373:n1501 http://dx.doi.org/10.1136/bmj.n1501 Published: 11 June 2021

\title{
Pandemic preparedness: UK government kept coronavirus modelling secret
}

\section{Clare Dyer}

The UK government modelled a coronavirus pandemic five years ago but kept the fact secret from parliament, a campaigning doctor has discovered through a Freedom of Information Act request.

A list released by Public Health England shows for the first time that 11 pandemic and epidemic preparedness exercises were carried out between 2015 and 2019. They included Exercise Alice, which in 2016 tested the country's readiness to cope with Middle East respiratory syndrome, caused by a coronavirus.

Moosa Qureshi, an NHS consultant haematologist, has been waging a legal battle for transparency since the SARS-CoV-2 pandemic broke out in early 2020. ${ }^{12}$ His efforts led to the disclosure that the government had modelled an influenza pandemic in Exercise Cygnus in 2016, ${ }^{3}$ but the existence of the other exercises has only now come to light. Apart from influenza and MERS, the other exercises modelled outbreaks of avian flu, Ebola virus disease, and Lassa fever.

Public Health England initially refused to answer his request for information on other modelling exercises on the grounds of national security. It was only after Qureshi asked for the decision to be reviewed that the list was released.

But Public Health England still insists that it would damage national security to release reports on the exercises, apart from that on Exercise Cygnus. Qureshi has complained to the Information Commissioner's Office.

Matt Hancock, the health and social care secretary for England, told MPs after the list was released, "Famously, all the preparations and the plans that were in place were for a flu pandemic. Novel coronavirus, as we'll come to when we talk about asymptomatic transmission, is different from even the previous coronaviruses, including SARS and MERS."

Giving evidence before the parliamentary joint committees on science and technology, and health and social care, he added, "It's true that the countries that experienced SARS and MERS were better prepared than we were, partly because of that experience. But it is also true that covid-19 is very different from SARS and MERS, and the number one difference is that it has asymptomatic transmission."

Qureshi said, “The health secretary told parliament that Exercise Cygnus looked at UK preparedness for a flu pandemic, not other pandemics, but the truth is that he's covering up multiple secret reports on preparedness for other pandemics, including a coronavirus pandemic. Politicians need to stop playing 'Yes, Minister' and understand that pandemic preparedness is improved by transparency and public scrutiny."

Peter Openshaw, an immunologist and professor of experimental medicine at Imperial College London and a member of the government's Nervtag committee, which advises on new and emerging respiratory virus threats, told The BMJ, "It does seem surprising that those exercises weren't presented to scientific advisory committees. It would be interesting to raise it on Nervtag."

David Matthews, a reader in virology at Bristol University, told the Guardian that the MERS exercise "would have been completely relevant" to the government's response to covid-19. ${ }^{4}$

A government spokesperson said, "We have always been clear that we undertake exercises regularly, both at a national and local level, as they are an essential part of assessing both our pandemic preparedness and planning for a wide range of scenarios. The lessons learnt from these exercises have contributed to our ability to rapidly respond to this unprecedented global crisis and continue to be considered by the government and a range of stakeholders, including expert advisory groups and local emergency planners, in reviewing pandemic response plans.”

1 Dyer C. Pandemic preparedness: doctor leads campaign for UK government to release report. BM/2020;369:m1732. doi: 10.1136/bmj.m1732 pmid: 32349981

2 lacobucci G. Pandemic preparedness: Government must release 2016 report, says information commissioner. BMJ2020;371:m3953. doi: 10.1136/bmi.m3953 pmid: 33046458

3 Dyer C. Report of UK's pandemic preparedness leaves questions unanswered, says doctor. BM/2020;371:m4499. doi: $10.1136 /$ bmj.m4499 pmid: 33208320

4 Booth R. Secret planning exercise in 2016 modelled impact of Mers outbreak in UK. Guardian. 10 Jun 2021. https://www.theguardian.com/society/2021/jun/10/secret-planning-exercise-in-2016-modelled-impact-ofmers-outbreak-in-uk.

This article is made freely available for use in accordance with BMJ's website terms and conditions for the duration of the covid-19 pandemic or until otherwise determined by BMJ. You may use, download and print the article for any lawful, non-commercial purpose (including text and data mining) provided that all copyright notices and trade marks are retained. 